\title{
Meta
}

Journal des traducteurs

Translators' Journal

\section{The Hidden Words of Baha'u'llah: Translation Norms Employed by Shoghi Effendi}

\section{Diana Malouf}

Volume 31, numéro 3, septembre 1986

Prismes de traductions littéraires

Facets of Literary Translation

URI : https://id.erudit.org/iderudit/003547ar

DOI : https://doi.org/10.7202/003547ar

Aller au sommaire du numéro

Éditeur(s)

Les Presses de l'Université de Montréal

ISSN

0026-0452 (imprimé)

1492-1421 (numérique)

Découvrir la revue

Citer cet article

Malouf, D. (1986). The Hidden Words of Baha'u'llah: Translation Norms

Employed by Shoghi Effendi. Meta, 31(3), 350-360.

https://doi.org/10.7202/003547ar 


\section{THE HIDDEN WORDS OF BAHA'U'LLAH : TRANSLATION NORMS EMPLOYED BY SHOGHI EFFENDI}

Diana MaLOUF

SUNY-BINGHAMTON, USA

Shoghi Effendi (1896-1957), the great grandson of Baha'u'llah (1817-1892), Founder of the Baha'i Faith and Author of The Hidden Words, was born in Akka, Palestine of Persian heritage. (Baha'u'llah had been exiled with his family from Persia in 1853, spent ten years in Baghdad, was sent to Constantinople for four months, then to Adrianople for five years, and finally arrived in Akka August 31, 1868, where he died in 1892 after forty years imprisonment.) Thus, Shoghi Effendi's native language was Persian, and, additionally, having been born and raised in an Arab land, he was deeply steeped in Arabic. His grandfather, Abdu'l-Baha, Leader of the Baha'i Faith after Baha'u'llah's death, realized his grandson's potential and the future service he would render to the world Baha'i community and carefully plotted his academic career in preparation for his future work. He sent Shoghi Effendi to the American University of Beirut with the intention of his becoming proficient in English. From there he was sent to Oxford University in England, where though he did not complete his studies due to Abdu'l-Baha's death and his being recalled to Haifa, he did attain a highly polished and exemplary mastery of the English language. This prepared him for his role (among many others including Guardianship and administrator of the Baha'i World Center) of translator of the Sacred Writings of the three Central Figures of the Baha'i Faith : the Bab, Forerunner of Baha'u'llah (1819-1850); Baha'u'llah ; and Abdu'l-Baha, His son. But of particular interest is his appointment as Interpreter and Expounder of the Bahā'i Sacred Writings, rendering him the first person in religious history who was at one and the same time the sole authorized interpreter of the text he was translating. It will be observed as we go along that his function of interpretation overrides the other norms.

The Writings of the Baha'i Faith were penned in Persian and Arabic. Baha'ullah used both, but more are in Arabic than in Persian. Baha'ullah's Writings cover a number of different types including epistolary writings, poetry, law, theological treatises, and ethical writings, in which category is The Hidden Words, one of his primary works :

Shoghi Effendi tells in God Passes By how Baha'ullah in the year 1858 was inspired with the "gemlike utterances" which compose this book as He paced, wrapped in meditation, the banks of the Tigris. Shoghi Effendi indicates that the work is to be identified with the Hidden Book of Fatimah, which was believed to have been revealed by the Angel Gabriel through the Imam Ali for the consolation of muhhammad's grief-stricken daughter after the Prophet's death, but which has remained hidden from the world's knowledge till now made known. He describes it as "dynamic spiritual leaven cast into the life of the world for the reorientation of the minds of men, the edification of their souls and the rectification of their conduct," and ranks it as pre-eminent among the Author's ethical works'.

The Hidden Words, then, takes a very important position among Baha'u'llah's utterances for a number of reasons. It is a book re-revealed after an interim of some 1364 
lunar years, known as the "Hidden Book of Fatima" (considered the holiest woman in the Islamic dispensation) among early Baha'is, which, according to the traditions of Shi'ah Islam, was revealed to her by "the Holy Spirit personified as the Angel Gabriel" who "descended upon her and addressed certain words to her" to console her in her bereavement at the death of her Father, Muhammad ${ }^{2}$. Also the purpose of the book which is "a perfect guide-book for man on his journey to the spiritual worlds of God" edifies the work $^{3}$. Not the least is the grandeur and beauty of the language Baha'u'llah used which further enhances the work and gives it weight and import.

The book's importance is one of the reasons I have chosen it to examine in light of disclosing the norms, or policies, that Shoghi Effendi employed in its translation. Its structure easily lends it to scrutiny since it is composed of discrete parts ; for though the work is a whole and complete work made up of its interweaving components, yet its sententious individual elements can be lifted out to stand alone. The Hidden Words has two parts : the first, Arabic, and the second, Persian. Though I will confine this study to Part I - from the Arabic, it would do well to describe its total structure and design :

The book appears in two parts, the first of which was originally written in Arabic, the second in Persian. The reader soon perceives that though the subject of the two sections and the manner in which the material is arranged are the same yet there are other distinctions than that of language. The Arabic part is shorter than the Persian, 19 pages as against 33 ; it is more simple, direct, definite, ethical, the other more personal, appealing, mystical, poetical. The Arabic verses are all addressed to 'Son' or 'Child' : the Persian addresses are greatly varied, as "O Fleeting Shadow", "O ye Dwellers in the Highest Paradise", "O Essence of Desire", "O Companion of My Throne", "O Ye Rich Ones on Earth", "O Ye Peoples of the World", "O Oppressors on Earth", "O Emigrants", "O Weed that springeth out of Dust", and many such contransted phrases. The Arabic verses are directed to individuals, with the exception of numbers $67,68,69$; the Persian section has thirty-three directions to groups. The approach, the tone of the Author, is different in the two parts : the writer in Arabic is a loving teacher, the writer in Persian a teaching lover... Yet the Prologue to the Arabic portion, describing the nature of the work : "this is that which hath descended from the realm of glory uttered by the Prophets of old..." applies equally to the Persian portion. And the Epilogue at the end of the Persian, applies likewise to the Arabic. And all the stanzas that make up the work, one hundred and fifty and three, are in their meaning and substance so closely interwoven and interdependent that they form one integrated whole ${ }^{4}$.

It would be very interesting to compare the norms and policies Shoghi Effendi used in translating the Arabic text with that of the Persian text, but I must leave that for future study. I would venture, though, that they most probably are quite the same since Shoghi Effendi's purposes for translating the work would surely apply to both parts.

The Hidden Words was published in 1932 and is a product of Shoghi Effendi's first decade of translation production. His other translations of the Baha'i Writings use much the same tone and style as we find in The Hidden Words. The significant consideration here is that Shoghi Effendi set the model which future translators, though few in number, have emulated. Thus we can begin to see the scope of his work for the Baha'i Writings have now been translated in over 800 languages and dialects, using Shoghi Effendi's English translations of the Arabic and Persian as the language from which to translate into all the other world-wide languages, though "his actual instructions was to use his English translation together with the original 5 ." However, Arabists and Persian scholars capable of translating these works are rare (which accounts for the very small number, perhaps ten percent, of the Baha'i Writings having been translated to date); so Shoghi Effendi by using English, which is now a world lingua franca, as his medium, has made these Writings accessible through intermediate, "second-hand" translation 
(translation of a translation) to a world-wide congregation. The importance of the norms he used then can be easily surmised.

By discovering these norms and seeing if they apply to other of his translations if in fact not to all - we may be enabled to facilitate the ongoing, but painfully slow, process of translation from the Arabic (and probably Persian) into English. The following chart illustrates the progression of the translation of the Baha' $i$ Writings :

\section{Original Writings Arabic}

Persian

\author{
Shoghi Effendi's \\ English \\ Translations
}

\author{
Those \\ Literate \\ in English \\ Worldwide
}

Other Languages

of the World

(To Date Over 800)

\author{
Other Languages \\ Using Shoghi Ef- \\ fendi's Transla- \\ tions as a Model \\ and the Original \\ Text if Possible
}

In Translation Studies, which is a relatively new field, the function of norms has come under increasing scrutiny as a possible means of evolving a viable translation theory, so far elusive. It is agreed, however, that norms play a major part in the process of translation. It would be helpful at this point before proceeding to analyze Shoghi Effendi's norms in The Hidden Words to elucidate concepts of adequacy and equivalence and the function of norms in the process of translation. The concept of norms in translation has its corrolary in societal norms. Toury defines the relationship thus :

1.0 Literary translation, like any other behavioral activity, is subject to constraints of several types and varying degree. These constraints can be described along a scale anchored between two extremes : objective, relatively absolute rules (in certain behavioral domains, even stable, formulated laws) on the one hand, and fully subjective idiosyncrasies on the other. In between these two poles lies a middle-ground occupied by intersubjective factors, commonly designated "norms". The norms themselves do not occupy merely one point of the scale, but a graduated section of the entire continuum.

Sociologists and social psychologists regard norms as the translation of general values or ideas shared by a certain community - as to what is right and wrong, adequate and inadequate - into specific performance-instructions appropriate for and applicable to specific situations, providing they are not [yet] formulated as laws ${ }^{6}$.

Though norms are not laws, they do act as a form of control and order - in literature as well as in other facets of life. In literature they allow a literary system to exist, for without them there would be no regularity in, predictability or cohesion of the literaty system and, hence, no guide for the writer either to adhere to or break, within limits, in order to create a new evolution of a part of the literary system. Beyond norms there is the idiosyncratic behavior of the translator. This is not norm-governed and can only be explained in terms of idiosyncrasy, or subjective behavior, which is common in translators at one time or another, but does not govern the majority of choices which are usually norm-governed. 
Adequacy and equivalence are two terms introduced by Evan-Zohar which are used to denote opposite poles of translation production. A Source Text (ST) in a Source Language (SL), and here we shall consider literary texts, is a Source Text in a literary system or Source System (SS), a whole synchronic and diachronic development of a literature encoded in a Source Language, with all of its richness, nuances, and accompanying complexities. A translation into a Target Language (TL) of such a Source Text that retains the Source Text's form, structure, syntax, metaphorical language, etc. is an "Adequate" translation. This is a very rare phenomenon for a number of reasons, primary among them is that the resultant translation may well be incomprehensible and inaccessible to the TL audience and, therefore, unacceptable. In other words, we would be imposing the rules, structure and cultural background of the SL and SS on the TL and TS which, in most cases, are unsuitable vehicles for carrying such a transposition. Therefore, the "Adequate" translation is more of a hypothetical model and tool for theorists than a reality :

If ... adopted, as an overall strategy, or concerning certain parts or even only details, the translation tends to adhere to the norms of the original work, and through them - as well - to the norms of SL and/or the source literary polysystem as a whole. This tendency, which we shall call ... the pursuit of an adequate translation, may mean - or cause - incompatibility of the translated text with the target linguistic and/or literary norms?

The most usual solution is the "Equivalent" translation which plugs in the most appropriate "equivalent" or "equal" component which would be in keeping with the capabilities and requirements of the TS. This is accomplished by adhering to the norms of the target linguistic and literary system :

If, ... adopted, the operational linguistic and literary norms of the target system are triggered and set into full operation. Whereas adherence to the norms of the original determines the adequacy of the translation as compared to it, adherence to the norms of the target determines its acceptability in the target linguistic and/or literary polysystems as well as its exact position within them ${ }^{8}$.

Of course, both source and target literatures and the norms which govern them are in a constant state of flux and change and there must be consideration taken in a study of a translation to the time period in which the ST was written and the time period of the TT and the resultant norms governing the decisions made in producing the translation. This can start to get very complicated since one can choose a style of TL in which to render a literary text which antedates the current literary style. This, in fact, is the case with Shoghi Effendi's choice of the English "Biblical" style used in The Hidden Words. Such a study of the English stylistics, and the Arabic too, though intended for the future, is beyond the scope of this paper.

What shall be given attention here are the norms Shoghi Effendi followed as guidelines for his translations, and, in order to understand his choices, an explanation of his purpose and intention in translating the work must be examined. After his initial function of providing and authorized translation of the work, in his capacity of Interpreter, he was dedicated to the promulgation of a new world religion and to nurturing a growing world-wide community of believers. Every major religon, Judaism, Christianity, Islam, Zoroastrianism, Bhuddism, and Hinduism, has a scripture, which is a solace and guide to its followers and a proof of the religion's validity. Shoghi Effendi desired to provide the Baha'is of the world with a translation of the religion's scripture, both to succor the believers and to assert the right of the Baha'i Faith to exist as an inde- 
pendent world religion (having its own Holy Writ). He confined himself to translating the major works, since just Baha'u'llah's Writings alone are equivalent to 100 volumes.

The norms I have discovered in The Hidden Words are congruent with the abovementioned objectives. Shoghi Effendi provides a clear and understandable and beautiful text, and elevates that text by giving it a proper style of English befitting scripture which evokes in the reader the attitude of reverence and respect reserved for a religious text. His translations reflects the following policies :

1. Interpretation and clarification of the text.

2. Elevation of the tone of the language to befif Holy Writ.

3. Beautification of the English text.

4. Euphonization of the translation.

In determining the norms of a translation, the examination of 3-5 pages is normally sufficient and not more than 15 pages. For most literary texts, including novel length, 5 pages of the work is quite adequate for someone trained in the technique. Though the translation of the Arabic Hidden Words is only 19 pages long, I have analyzed $31 / 2$ pages of the English by comparing it with the Arabic (42/3 pages). This came to 11 of the 71 Hidden Words, plus the Prologue (Prologue and numbers 1, 2, 3, $21,22,23,24,48,29,50$ and 51 ) ; in other words, 12 out of 72 components of the text. I will now proceed to elucidate these policies and give examples, contenting myself with two or three examples for each norm. (A full listing of the norms in the passages I examined can be found in the Index.) It must be noted that norms often overlap, being used for different ends and being subordinated to one another depending upon what immediate purpose they are serving. Also in some instances a norm cannot be determined or, at least, not with certainty or without further, sometimes extended, research. (In the Index I have indicated this situation with a question mark.)

Norm 1 : Clarify and interpret the text

The primary policy of Shoghi Effendi as Interpreter and Expounder, is to clarify and interpret the work so that there is no mistaking the meaning, so elemental to a scriptural text. A most important function of such a text is to educate, guide, and modify behavior, which emanates from imparting the meaning. Maintaining the meaning free of corruption is paramount. In this light, Shoghi Effendi uses a number of devices to attain clarity in meaning. In line 10 of Hidden Word Number Two, above, we have 'loving-kindness' which translates the common first dictionary meaning of 'concern, interest' (عســـ in the Arabic. The clarifies the intent of the original by making if more specific and descriptive than the broader terms, 'concern' or 'interest'; it is a concern that embraces love and kindness.

Another good example is in Hidden Word Number Two (line 4) above : "... and neglect it not that I may confide in thee." The phrase 'that I may confide in thee' clarifies the Arabic 'that you may be trustworthy with me' (مسنه لـتكون لي أهسينـان) ولا تففل (و) Only one trustworthy can be confided in (and, of course, can do other things too). So here Shoghi Effendi takes the prerogative to indicate just what is meant by this.

Norm 2 : Elevate the tone of the language to befit Holy Writ

Shoghi Effendi elevated the tone of the translation by using a form of "Biblical" English, not, however, King Jamesian. The style is in general along the lines of the English used in the Victorian era for translations of the Koran, the Islamic Holy Book, and other Near Eastern literature. I hope to do further research on this point, but it is beyond the purport of this paper, and so these few words will have to suffice. Neverthe- 
less, in a purusal of the text it is quite obvious that this is so. For example, words pertaining to the Deity or his Messengers are capitalized, as they are in the Bible :

This is that which hath descended from the realm of glory,

uttered by the tongue of power and might, and revealed 2

unto the Prophets of old. We have taken the inner essence 3

thereof and clothed it in the garment of brevity, as a token 4

of grace unto the righteous, that they may stand faithful 5

unto the Covenant of God, may fulfill in their lives His 6

trust, and in the realm of spirit obtain the gem of Divine 7

virtue?.

Here we see 'Prophets' (line 3) capitalized, which refers to the Messengers throughout the ages. The word 'God' (line 6) would normally be capitalized as a spelling convention in English, but the capitalization of 'His' (line 6) and even 'Divine' (line 7) lend the text a reverent tone. This can be further seen in Hidden Word Number Four :

\section{O SON OF MAN!}

I loved thy creation, hence I created thee. Where-

In this instance 'Me' is capitalized, which refers to God, as the source of the revelation uttered by His Messenger, Baha'u'llah : so two voices are included in the 'Me'. A reading of the text will show that this policy is followed throughout.

Another technique which elevates the text can be discerned from these same passages : namely, the use of the archaic form of verbs and personal and possessive pronouns. Thus we see in the Prologue (line 1) 'hath descended' for the 'has descended' of modern usage. Again in Hidden Words Number Four (line 2) the archaic possessive pronoun 'thy' replaces the modern 'your'; and in line 3 the personal pronoun 'thou' is used for 'you'. These substitutions are archaic and were used in the King James Bible. Here they biblicize the text, and therefore elevate it. This device also is consistent throughout the translation and is intended to convey the idea that the text is Holy Writ and to elicit the appropriate attitude in the reader.

Another device elevating the translation is inversion, which also gives emphasis to the statement and is frequently used in the Bible; this stylistic element imparts authority to the text to instruct the reader :

23. O SON OF THE SUPREME!

To the eternal I call thee, yet thou dost seek that 2

which perisheth. What hath made thee turn away from

Our desire and seek thine own ${ }^{11}$ ?

The more usual sequence in line 2 would be "I call thee to the eternal." The inversion of normal word order here is in harmony with an archaicized biblical style and adds emphasis and authority to the passage. 


\section{Norm 3 : Beautify the English text}

Shoghi Effendi also beautified the English text making it a suitable vehicle for divine inspiration :

21. O SON OF MAN!

Upon the tree of effulgent glory I have hung for

thee the choicest fruits, wherefore hast thou

turned away and contented thyself with that which

is less good? Return then unto that which is better

for thee in the realm on high ${ }^{12}$.

The word 'realm' replaces the common choice, 'horizon' (أفق) in the orignal, which is more lovely than the clumsier 'horizon' would be in English. However, overriding this observation is his functioning as Interpretes and clarifying the meaning for the reader. Here is a very good instance of norms overlapping. First interpretations, and, second, beautification.

Another instance of beautification is observed in Hidden Word Number 3 :

3. O SON OF MAN!

Veiled in My immemorial being and in the ancient

eternity of My essence, I knew My love for thee;

therefore I created thee, have engraved on thee

Mine image and revealed to thee My beauty ${ }^{13}$.

The word 'engraved' here clarifies 'to throw ; put' and gives a more poetical reading. The alliteration fo the ' $V$ ' sound in 'Veiled', 'love', 'engraved', and 'revealed' also poeti-. cize, as well as emphasize, the translation.

Hidden Word Number Two illustrates beautification using addition and substitution of words :

\section{O SON OF SPIRIT !}

The best beloved of all things in My sight is Jus-

tice; turn not away therefrom if thou desirest

$\mathrm{Me}$, and neglect it not that I may confide in thee.

By its aid thou shalt see with thine own eyes and

not through the eyes of others, and shalt know of

thine own knowledge and not through the knowl-

edge of thy neighbor. Ponder this in thy heart;

how it behooveth thee to be. Verity justice is My

The phrase 'in My sight' clarifies the Arabic 'with me' or 'I have' (عندي), and this at the same time beautifies the text. 
Shoghi Effendi uses another technique of not repeating the same word in close proximity - a norm in English, but not in Arabic, which enhances the readability of the text :

1. O SON OF SPIRIT! 1

My first counsel is this : Possess a pure, kindly and 2

radiant heart, that thine may be a sovereignty

ancient, imperishable and everlasting ${ }^{15}$.

In line 4 the phrase 'ancient, imperishable and everlasting' reads in the Arabic : 'always, eternal, eternal, ancient' (four different words in Arabic, two with the same primary dictionary meaning). This repetition of 'eternal' would be entirely unacceptable in English. He has employed 'imperishable' and 'everlasting' — both meaning 'eternal,' but which broaden and further clarify the meaning by adding facets to it. He has also ommitted

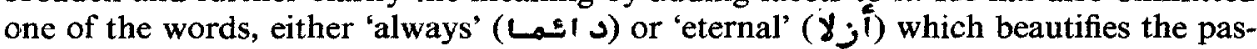
sage - namely, readability. Also the word order is here inverted : 'ancient' is the first word of the passage in English, whereas in the Arabic it is the fourth in the string (د أتمـا بـاقييا أزلا تديما in قديما ).

Norm 4 : Euphonize the translation.

Another policy of Shoghi Effendi is to euphonize the text or make it more musical. Of course, this also beautifies it. The original is written in rhymed prose (س-جسc). Though this is not always possible, or desirable, in English, nonetheless, if one reads the English out loud there is a rhyme and rhythm to it, more obvious in some passages than in others. In Hidden Word Number Two, as above, lines 3 and $4:$ "turn not away therefrom if thou desirest $M e$, and neglect it not that I may confide in thee" (italics mine) have a correlative end rhyme in each phrase (underscored) and have the same meter. Not all instances are this close, but maintains the feel and music of the original. In the same passage (lines 5-8) "By its aid thou shalt see with thine own eyes and not through the eyes of others, and shalt know of thine own knowledge and not through the knowledge of thy neighbor." The rhyme at the end of each phrase (underscored) is close with the 'er'(s), 'or' sound, and the meter is the same with 18 syllables in each of the two phrases. This is precisely what the Arabic does in rhymed prose; each phrase has the same and rhyme and (more or less) same meter. Shoghi Effendi accomplishes this in the English in an unobtrusive fashion.

It is important to note that the norms we have been discussing overlap and that a number of devices are used for the achievement of one policy as well as another and also simultaneously. A glance at the Index indicates how complex this can become, and I will also say that further development of the material would reveal more relationships and further complexity. An example is the euphonics which are everywhere apparent, but which I have not noted, and, since Shoghi Effendi is authorized Interpreter, the whole of The Hidden Words is considered to be interpretation.

Shoghi Effendi uses a variety of means to pursue four policies : above all to interpret the translation, and then to elevate, beautify and euphonize the text. To these ends he utilizes addition, omission, variation, rhyme, meter and Biblical style. His purpose is to make the text accessible to the reader. He has chosen an equivalent translation which, though retaining all original elements, even if foreign to the English literary polysystem, such as unusual imagery, references to Sufistic symbolism and expression, still strives to fit into the English literary system. He wants this work to be acceptable for only then can it fulfill its objective - to guide lives, mold behavior and uphat mans 
spiritual life. He has chosen a Biblical style of English which fits our expectations for a religious text and elevates it in our eyes. He has beautified the text with careful and poetic choice of words and has euphonized it with rhyme and loose meter in a poetic prose style, which attempts to reproduce the feel of the Arabic rhymed prose original, hence making it more appealing and elevated. And he does his utmost to impart to the reader the meaning of the text, its most fundamental element. By doing so he seeks to render a translation that will have the effect on the reader that the original evokes. For those who are privileged to read the original Arabic, his translation has been a consummate success.

Notes

1. Georges Townsend, preface to Baha'u'llah, The Hidden Words, trans. Shoghi Effendi, Wilmette, Illinois : Baha'i Publishing Committee, 1932, p. i.

2. Taherzadeh, Adib (19-) : The Revelation of Baha' ' 'llah : Baghdad 1853-63, Oxford, England : George Ronald, p. 71.

3. Taherzadeh, p. 72 .

4. Baha'u'llah, p. ii.

5. Gideon, Toury (1980) : In Search of a Theory of Translation, Jerusalem : Academic Press, p. 51.

6. Toury, p. 55.

7. Toury, p. 55.

8. Even-Zohar, lecture at the State University of New York at Binghamton, January 26, 1984, my notes, p. 29.

9. Baha'u'llah, p. 3.

10. Baha'u'llah, p. 4.

11. Baha'u'llah, p. 9.

12. Baha'u'llah, p. 15

13. Baha'u'llah, p. 9.

14. Baha'u'llah, p. 4.

15. Baha'u'llah, pp. 3-4.

\section{BIBLIOGRAPHY}

BAHA'U'LLAH (1932) : The Hidden Words, trans. Shoghi Effendi, Wilmette, Illinois : Baha'i Publishing Committee.

TAHERZADEH, Adib (19-): The Revelation of Baha' ' 'llah : Baghdad 1853-63, Oxford, England : George Ronald.

TOURY, Gideon (1980) : In Search of a Theory of Translation, Jerusalem : Academic Press.

\section{INDEX}

\section{Prologue}

Invocation Change. Arabic reads 'He is the Glorious, the Most Glorious.'

lines 1,2 Clarification. نز translated into 'descend' and 'reveal' each of which compliments the meaning.

lines 1,2 Variation. Uses two different words for

line 4 Clarification. Used 'inner essence' instead of just 'essence'.

line 5 Biblical style. 'thereof' instead of 'its.'

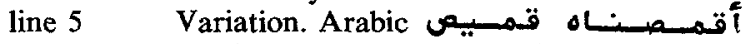

line 5 Addition. 'token' is an addition. Arabic has only فضـل فـل Clarification.

line 6 Change in word. Clarification. 'righteous' instead of 'learned man ; non-Muslim religious authority.'

lines $6 \& 7$ Variation. Biblical style. Clarification. Bothwif'fulfill' and other meanings. 'stand faithful' has a very Biblical feel and also instructs (clarification) what the 'righteous' do. 
line 7 Clarification. Create term or expression. لـا عـ by using initial 'caps' indicates a specific concept in Writings - specific thing. 'lives' for 'their selves' (1). Change.

line 7 Biblical style. Arabic does not use capitals as in English. 'His' is capitalized to refer to God.

line 8 Ommission. Accessibility. The emphatic ' $U$ ' has no counterpart in the English.

line 8 Emphasis. Clarification. Beautification. Uses Verb instead of noun. 'obtain' is indicated in the Arabic by فـاكٔزين.

\section{Hidden Word Number One}

line 1 Addition. Clarification. Immediacy. Instruction. Used 'My ... is this' - made it a command.

line 1 Change of words, substitution. Used 'pure' for 'جسبد أ 'وفيد', 'good, excellent,' but can

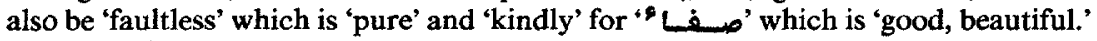
Beautification.

line 4 Elimination. Inversion. Accessibility. Eliminated (or combined ' أَ' ' which both mean 'eternal.' Put one word for the two : 'everlasting.'

line 4 Variation. Same as above.

line 4 Inversion. Order is inverted. Also Beautification. Euphony.

\section{Hidden Word Number Two}

line 2 Addition. Beautification. Clarification. Added 'all' although ' * 'لأشسيـ I' means ('all) things.'

line 2 Change. Substitution. 'I have; with me' translated as 'in My sight' which also beautifies, clarifies.

line 3 Biblical style. Elevation. Inversion. Puts 'not' after object instead of in front of verb.

line 4 Euphony. Beautification. Accessibility. Change, Substitution. 'Me' and 'thee' keep same rhyme position as 'أ أمسينــ' Meter matches also. 'that I may confide in thee' translates 'that you may be trustworthy with me.'

line 5 (?). Elimination. " " cessibility. 'By its aid" for 'you will be given success (by God) in this (justice).' 'thine' for 'your.' 'eyes' for 'eye' (عين).

lines 5-8 Euphony. Accessibility. Beautification. Elevation. 'shalt' for 'shall.'

lines 8-10 Euphony. Beautification. Accessibility. 'the eyes of others' for 'eye of the servants' ( عبين السعبـاد ).

line 11 Elevation. 'thine' for 'your.' Elimination. 'Lo' eliminated - refers back to 'things' (") which was also eliminated. Beautification.

lines 11-12 Substitution. Elimination. Beautification. Clarification. 'through the knowledge of thy neighbor' instead of 'throught the knowledge of anyone in the "country ", (بمعرفة أحسـد في ألبلاد

line 12 Elevation. 'thy' for 'your.' 'behooveth' is archaic. Addition. 'thy hear' not in Arabic.

line 13 Clarification. 'J' refers to 'justice'; put 'justice is...' instead of 'this is...' Emphasis. Addition. Elevation. 'Verily...'

line 14 Addition. Clarification. Beautification. 'loving-kindness' for 'concern, interest'

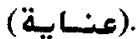

line 15 Inversion for emphasis. 'then' in middle of sentence which is more emphatic than at beginning.

Hidden Word Number Three

line 2 Elevation. 'My' in 'caps.' Addition. Clarification. 'Veiled' and 'ancient' not in Arabic.

line 4 Addition. Clarification. 'therefore' not in Arabic. Beautification. 'engraved' for 'throw ; put' (ألققى).

lines 4-5 Elevation. 'thee' ; 'Mine'; 'My' in initial 'caps.' 
Hidden Word Number Twenty-One

line 2 Substitution. Change. Clarification. Beautification. 'hung' for 'ordain, decree' ; completes the metaphor.

line 3 Elevation, 'thee' for 'you,' 'wherefore' for 'how' and 'hast' for 'have.'

line 4 Inversion. Emphasis. 'then' after 'return' instead of first as in normal word order.

line 6 Change, Substitution. Beautification. Explication. 'realm' for 'horizon.'

Hidden Word Number Twenty-Two

line 2 Inversion. Emphasis. Elevation. 'Noble have' at beginning of sentence and not after. 'thee,' 'thou,' 'hast.'

line 3 Elevation. 'thou wast' instead of 'you were.' Inversion. 'then' after 'rise.'

\section{Hidden Word Number Twenty-Three}

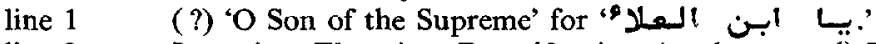

line 2 Inversion. Elevation. Beautification. 'to the eternail) I call thee.'

line 3 Elevation. 'perisheth,' 'hath,' 'thee.'

line 4 Elevation. 'thine.'

Hidden Word Number Twenty-Four

line 2 (?) 'Transgress' for 'تتنعد.'

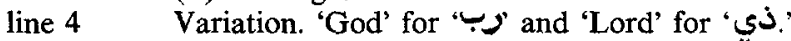

Hidden Word Number Forty-Eight

line 2 Inversion. Elevation. 'For everything there is a sign.'

lines 3-4 Elevation. 'My' in 'caps' (God and Prophet speaking).

\section{Hidden Word Number Forty-Nine}

line 2 Elevation. 'yearneth' for 'yearns.'

line 3 Addition. Beautification. 'doth' to make a verb.

\section{Hidden Word Number Fifty}

line 2 Elevation. 'My,' 'thee.'

line 4 Elimination. 'and' (9) eliminated and made into two sentences. Beautification.

lines 4-5 Elevation. Beautification. 'My,' 'thee,' 'wilt.'

line 5 Change. Clarification. 'attain' for 'befall you.' 